\title{
Change and Stability in Public Beliefs About Same-Sex Family Rights in Norway in 2008, 2013, and 2017
}

\author{
Ragnhild Hollekim ${ }^{1} \cdot$ Norman Anderssen ${ }^{2,3}$
}

Accepted: 7 February 2021 / Published online: 22 March 2021

(c) The Author(s) 2021

\begin{abstract}
Introduction In Norway, legal measures securing equal marriage and parenting rights for same- and different-sex couples took effect on January 1, 2009. The aim of this study was to assess Norwegian public beliefs about lesbian and gay family rights in the period of 2008-2017.

Methods Three nationwide surveys representing the adult Norwegian population were conducted with a time series design (data collected in 2008, 2013, and 2017, $n=1246,1250$, and 1250, respectively) utilizing Web-based questionnaires.

Results Over the 9-year period, there was a decline in negative beliefs about lesbian and gay parenting and marriage rights and gradually less concern about children growing up with same-sex parents, more so for men than for women. Beliefs about equal parenting rights remained more negative than beliefs about equal marriage rights. At all points in time, concern for children's welfare was the strongest predictor of beliefs about equal parenting rights for same- and different-sex couples, and for all points in time, being older contributed to the explained variance.

Conclusions We discuss how the findings may relate to policy developments concerning LGBTI rights in Norway. LGBTI rights have gained increasingly significant symbolic value in the public domain, and we suggest that it is productive to reflect on findings in relation to new landscapes of political and public discourse in Norway and Europe.

Social Policy Implications The results reveal contemporary supportive public opinion regarding LGBTI family rights, which currently gives lawmakers a foundation for further institutionalizing LGBTI rights in domains such as in schools at every level and in institutions offering family support and counseling. However, there is also a need for political awareness of emerging discourses linking questions on same-sex family rights to broader divisive sociopolitical processes.
\end{abstract}

Keywords Lesbian and gay family rights $\cdot$ Parenting $\cdot$ Same-sex $\cdot$ Attitudes $\cdot$ Time series

\section{Introduction}

In 2000, no European country had yet introduced legal measures to allow same-sex couples to marry one another or adopt children. Less than two decades later, same-sex couples in a number of countries now have marriage and parenting rights similar to those of different-sex couples (ILGA-Europe, 2019). There are clear indications that

Ragnhild Hollekim

ragnhild.hollekim@uib.no

1 Department of Health Promotion and Development, Faculty of Psychology, University of Bergen, Bergen, Norway

2 Department of Psychosocial Science, Faculty of Psychology, University of Bergen, Bergen, Norway

3 Research Unit for General Practice, NORCE Norwegian Research Centre, Bergen, Norway public support for such rights has increased over time in many countries (Montero, 2014; Wilson, 2020); however, the picture is not uniform, and there is seemingly a complex nexus of relationships between public policy, public opinion, religion, and wider societal developments (Dotti Sani \& Quaranta, 2020). In this paper, we investigate, based on a time series design, change, and stability in Norwegian popular beliefs about lesbian and gay family rights from 2008 to 2017. This period coincides with the first decade of the implementation of the gender-neutral Marriage Act introduced January 1, 2009. Norway has a strong history of law and policy protection of LGBTI rights, including same-sex family rights. In the latter part of the article, we discuss findings in light of such policy developments concerning LGBTI rights in Norway. As LGBTI rights have acquired increasingly significant symbolic value in the public domain, we also discuss findings in relation to new 
landscapes of political and public discourse in Norway and Europe. Slootmaeckers et al. (2016) argue that, over the last 10-15 years, the rights of LGBTI people have become "an ever more salient and controversial topic in international politics" (p. 1).

Continuously, more countries are introducing legislation on same-sex family rights (ILGA-Europe, 2019). Concurrent with this, we see a positive as well as mixed picture of social attitudes toward such rights (Takács et al., 2016). In the Netherlands, the first country to introduce same-sex marriage rights (2001), $85 \%$ of the population supported these rights in 2013 (Lipka, 2013). In Norway, population support for equal marriage rights reached 58\% among men and $78 \%$ among women when the new gender-neutral Marriage Act was adopted in 2008 (Hollekim et al., 2012). Australia introduced a right for same-sex couples to marry in December 2017; however, in 2014, $72 \%$ of the population supported same-sex marriage rights (Cox, 2014). In 2015, in the USA, when the Supreme Court ruled that marriage is a fundamental right for all citizens, public support had risen to an approval rate of nearly 60\% (McCarthy, 2015). However, in countries such as Poland and Hungary, only $21 \%$ and $30 \%$ of the population, respectively, expressed support for samesex marriage (Lipka, 2013).

We see a similar development in attitudes toward parenting and adoption rights; however, in the European context, support for parenting rights has typically been somewhat lower. In the 2006 Eurobarometer Public Opinion Survey covering 27 countries, support for adoption rights for same-sex couples reached 32\%, $12 \%$ lower than support for equal marriage rights (European Commission, 2006). In Norway, support for equal adoption rights increased from $25 \%$ to barely $50 \%$ in the 10-year period between 1998 and 2008 (MMI, 1998; Hollekim et al., 2012), while in Germany, in 2013, public support for parenting rights for same-sex couples reached $71 \%$ (Lipka, 2013). While more than $80 \%$ of the populations of Great Britain and Germany supported the statement "gay men and lesbians should be free to live their own lives as they wish," in countries such as Russia, Ukraine, and Lithuania, less than $30 \%$ of the population supported this claim (European Social Survey, 2010).

We will briefly summarize recent and relevant research concerning what may affect population beliefs about samesex family rights. Negative beliefs about same-sex marriage and parenting rights are typically predicted by gender and age. Women and young people hold more positive opinions (Costa et al., 2018a; Costa et al., 2018b; Gross et al., 2017; Pistella et al., 2018; Sloane \& Robillard, 2018; Webb \& Chonody, 2012). Furthermore, other demographic variables such as education (lower), marital and parental status (being married and being a parent), religiosity (higher), and political leanings (conservative) predict negative attitudes toward such rights (Costa et al., 2018a; Costa et al., 2018b; Gross et al., 2017; Sloane \& Robillard, 2018; Webb \& Chonody, 2012). Importantly, research typically supports the importance of gender ideology or socially prescribed gender norms when trying to understand attitudes toward same-sex families (Gato \& Fontaine, 2015; Webb et al., 2017), indicating that traditional (conservative) gender belief systems contribute when trying to explain beliefs about same-sex family rights (Costa et al., 2018b; Pistella et al., 2018).

Attitudes toward same-sex family rights have increasingly been explored in relation to lawmaking and the implementation of civil rights law in this field. Research suggests that policy development on these issues may both legitimate (Hooghe \& Meeusen, 2013) and reflect a growing consensus on social change (Flores \& Barclay, 2016). Abou-Chadi and Finnigan (2018), in studying data on legislation in the field of same-sex family rights from eight waves of the European Social Survey, found clear indications that marriage rights positively affect population beliefs. In their study on population attitudes following the Iowa Supreme Court's decision on same-sex marriage rights, Kreitzer et al. (2014) found increased public support for such rights. Similarly, Flores and Barclay (2016) found, following the US Supreme Court's decisions on same-sex marriage rights, a reduction in anti-gay attitudes in states that had introduced such legislation. However, and similar to Perrin et al. (2018), in studying the potential effect of same-sex marriage legalization on public support for such rights following the US Supreme Court ruling of 2015, Abou-Chadi and Finnigan (2018) observed findings that may suggest an attitudinal polarization effect following lawmaking in this area.

Support for same-sex family rights may vary based on country- or region-based characteristics. Based on data from the fourth round of the European Values Study (2008-2010), Takács et al. (2016) divided 28 countries into groups such as Social Democratic Welfare countries (Nordic countries), Liberal Welfare countries (e.g., France and the Netherlands), Southern European Familialistic Welfare countries (e.g., Greece and Italy), and Central European Post Socialist countries. They found considerable variation in support for same-sex adoption rights, where for example, Southern European Familialistic Welfare countries and Central European Post Socialist countries "stood out in terms of opposing the idea of same-sex adoption" (p. 1796). A strong relationship was identified between countries with legislation on same-sex adoption rights (relating in particular to Northern and Western countries) and positive attitudes on same-sex adoption, and these findings are supported by Dotti and Quaranta (2020) in their study on the issue of adoption by same-sex couples in 22 European countries based on data from the European Social Survey (2016-2017). Importantly, individual-level characteristics may operate differently in 
different contexts, indicating the existence of mixed opinions in more progressive countries and regions. For example, Dotti Sani and Quaranta (2020) found that irrespective of a country's status on the legalization of LGBTI rights, being young, secular, and having completed higher education were associated with more positive attitudes toward homosexuality. However, in relation to attitudes toward same-sex adoption, such associations were found only in countries that are progressive in relation to LGBTI rights (Dotti Sani \& Quaranta, 2020).

Norway was among the first countries to introduce legal protection for individuals from sexual minority groups. For example, protection from discrimination based on sexual orientation was included in the Discrimination Act from 1983. Similarly, Norway was the first of the Nordic countries to introduce a gender-neutral Marriage Act enforced since January 1, 2009. This law replaced a progressive Partnership Law from 1993, at large securing equal rights for LGB people with some exceptions, importantly marriage and family rights. The law compelled, however, a gradual allowance for same-sex couples to become foster parents (Ministry of Children and Equality, 2004), and the Law on Adoption of 2002 allowed for the adoption of one's partner's child in same-sex partnerships. Importantly, in Norway, a more contested Partnership Law (1993), which was only narrowly accepted by the Parliament, most likely paved the way for a more politically agreed upon and less contested gender-neutral Marriage Act (2009) (Roseneil et al., 2013). The Law on Discrimination adopted on January 1, 2014 aimed to widen rights to protection from discrimination in every area of society, and in a new and coordinated Equality and Anti-discrimination Act (2017), the Norwegian Parliament further secured LGBTI people from discrimination. Only recently on July 1, 2020, the Norwegian Law on Biotechnology permitted assisted fertilization for lesbian couples-egg donation will be legal from January 1, 2021 (Ministry of Health and Care Services, 2020). Becoming a parent by surrogacy is still illegal in Norway regardless of sexual orientation.

Although ILGA-Europe in 2017 rated Norway 2nd among the 49 European countries in terms of follow-up on LGBTI rights (ILGA-Europe, 2017), the historical time period considering LGBTI family rights is short, and the wider European sociopolitical landscape concerning samesex family issues has been unstable. Thus, Norwegian experiences may constitute an interesting case for understanding and reflecting on current processes involved in the development of public opinion on same-sex family rights. In the current analyses, we wanted to explore change and stability in Norwegian popular beliefs about lesbian and gay family rights in the decade following the implementation of the gender-neutral Marriage Act, including parenting rights equal to heterosexual couples. More specifically, we analyze beliefs about lesbian and gay parenting rights, about the welfare of children with same-sex parents, and about lesbian and gay marriage rights. We pay particular attention to public beliefs about same-sex parenting rights because this has been more contentious than same-sex marriage rights (European Commission, 2006). Additionally, this approach aligns with the focus of the first article included in our time series design (Hollekim et al., 2012).

\section{Methods}

\section{Design and Procedure}

The present analyses are based on a time series design with data from three national Web-based surveys of representative samples of the Norwegian adult population in 2008, 2013, and 2017. In the data collections, participants were recruited through a national panel established to represent the adult Norwegian population by the market analysis company Norstat. The panel consists of more than 75,000 persons who have agreed to participate in online surveys, and members are provided a symbolic reward for participation which they may hand over to charity such as Red Cross. The poll institute Opinion provided the link between the research group and the panel. For each data collection, panel members were randomly drawn and invited through email by Opinion to participate, including an introduction by the research group. Informants were told that by participating in the survey, they gave their consent. Each sample was stratified by age, gender and country region. The Norwegian Centre for Research Data concluded that the procedures did not elicit special ethic committee approval because participation was voluntary and conducted among informed and consenting adults. After providing the routine reward for participation, the responses were anonymized and stored at the Norwegian Centre for Research Data who delivered the three data files to the authors. The number of persons in each data collection who did not want to participate is not known. Internet coverage and use is widespread in Norway; in $2010,92 \%$ of the population used the internet weekly or more often, and the corresponding number in 2018 was $95 \%$ (including $81 \%$ of those aged 70 years or more) (Kompetanse Norge, 2020). Description of study design, some statistical analyses, and some comparisons from the data have been reported in Norwegian (Norwegian Directorate for Children, Youth \& Family Affairs, 2018).

\section{Samples}

There were three different samples. The 2008 sample consisted of 1246 participants, 653 (52.4\%) men and 593 women (47.6\%). In 2013, the sample consisted of 1250 
participants, $611(48.9 \%)$ men and 639 (51.1\%) women, and in 2017, the sample consisted of 1250 participants, 604 (48.3\%) men and 646 (51.7\%) women. Demographic profiles are displayed in Table 1. More men reported being a parent in 2008 (74\%) compared to 2013 (66\%) and 2017 (66\%). Women in 2008 were younger (38 years) compared to 2013 (48 years) and 2017 (49 years), fewer had higher education (56\%) compared to 2013 (64\%), and fewer reported being a parent (59\%) compared to 2013 (70\%) and 2017 (66\%).

\section{Measures}

The same measures were utilized at each data collection point. The current measures were developed in 2007 to assess contemporary public issues concerning beliefs about same-sex parenting rights and marriage. The three scales and items were developed at Department of Psychosocial Science at University of Bergen (Anderssen \& Slåtten, 2008), including the initial phrasing of the items and response categories. Two pilot studies were conducted, one in 2007 ( $n=207$ university students, including items on parenting and marriage rights) and one in 2008 ( $n=155$ university students and 37 employees in a private company, including items on the welfare of children growing up with same-sex parents and more items on parenting rights). The final questionnaire was adjusted according to comments from the pilot respondents regarding unclear formulation in the introductions and phrasing of questions. A neutral response-category ("neither agree nor disagree") was kept as an option because many preferred this, and we wanted to provide response alternatives that corresponded to the participants' true beliefs, although the pilot studies indicated that more respondents tended to respond with more negative responses in those groups were we did not include a neutral mid category.

Beliefs About Equal Parenting Rights for Lesbian, Gay, and Heterosexual Couples. This concept was operationalized by five statements expressing beliefs concerning the legal rights of lesbian and gay couples to become parents through adoption and state-sponsored assisted insemination (see Table 2). The response alternatives were "Completely agree," "Slightly agree," "Neither agree nor disagree," "Slightly disagree," "Completely disagree," and "Uncertain" (coded as missing except for cross tabulations). Responses were summed to create the scale "Beliefs about equal parenting rights for lesbian, gay and heterosexual couples," with high scores indicating positive attitudes. The scale had Cronbach's alpha values of 0.96 (2008), 0.96 (2013), and 0.94 (2017). Those who opposed granting lesbian and gay couples parenting rights on at least four out of five statements were classified as "Negative to equal parenting rights" in comparing groups based on selected background variables.

Beliefs About the Welfare of Children with Lesbian and Gay Parents. This scale consisted of eight statements (see Table 3); four items represented positive beliefs, and

Table 1 Description of the three samples-2008, 2013, 2017

\begin{tabular}{|c|c|c|c|c|}
\hline & 2008 & 2013 & 2017 & $F$ and post hoc analyses ${ }^{\mathrm{a}}$ \\
\hline \multicolumn{5}{|l|}{ Men } \\
\hline Mean age (SD) & $52.0(16.78)$ & $49.9(16.32)$ & $50.7(17.21)$ & $\mathrm{F}(2,1867)=2.64, \mathrm{p}=.072$ \\
\hline Education-college degree or higher & $398(61 \%)$ & $399(66 \%)$ & $378(64 \%)$ & $\mathrm{F}(2,1847)=1.32, \mathrm{p}=.267$ \\
\hline Population density—urban & $551(85 \%)$ & $500(82 \%)$ & $505(84 \%)$ & $\mathrm{F}(2,1859)=1.13, \mathrm{p}=.323$ \\
\hline Being parent & $481(74 \%)$ & $405(66 \%)$ & $398(66 \%)$ & $\begin{array}{l}F(2,1867)=5.70, p=.003 \\
2008 \text { vs. } 2013, p=.005 \\
2008 \text { vs. } 2017, p=.003 \\
2013 \text { vs. } 2017, p=.883\end{array}$ \\
\hline \multicolumn{5}{|l|}{ Women } \\
\hline Mean age (SD) & $37.6(14.42)$ & $48.2(16.52)$ & $48.6(17.94)$ & $\begin{array}{l}F(2,1877)=91.96, p=.000 \\
2008 \text { vs. } 2013, p=.000 \\
2008 \text { vs. } 2017, p=.000 \\
2013 \text { vs. } 2017, p=.666\end{array}$ \\
\hline Education-college degree or higher & $318(56 \%)$ & $404(64 \%)$ & $379(60 \%)$ & $\begin{array}{l}F(2,1847)=6.20, p=.002 \\
2008 \text { vs. } 2013, p=.000 \\
2008 \text { vs. } 2017, p=.072 \\
2013 \text { vs. } 2017, p=.073\end{array}$ \\
\hline Population density—urban & $519(88 \%)$ & $542(85 \%)$ & $555(87 \%)$ & $\mathrm{F}(2,1861)=0.91, \mathrm{p}=.403$ \\
\hline Being parent & $350(59 \%)$ & $449(70 \%)$ & $423(66 \%)$ & $\begin{array}{l}F(2,1877)=8.67, p=.000 \\
2008 \text { vs. } 2013, p=.000 \\
2008 \text { vs. } 2017, p=.017 \\
2013 \text { vs. } 2017, p=.071\end{array}$ \\
\hline
\end{tabular}

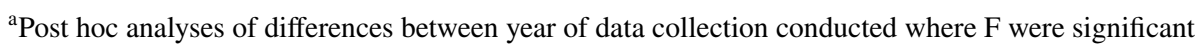




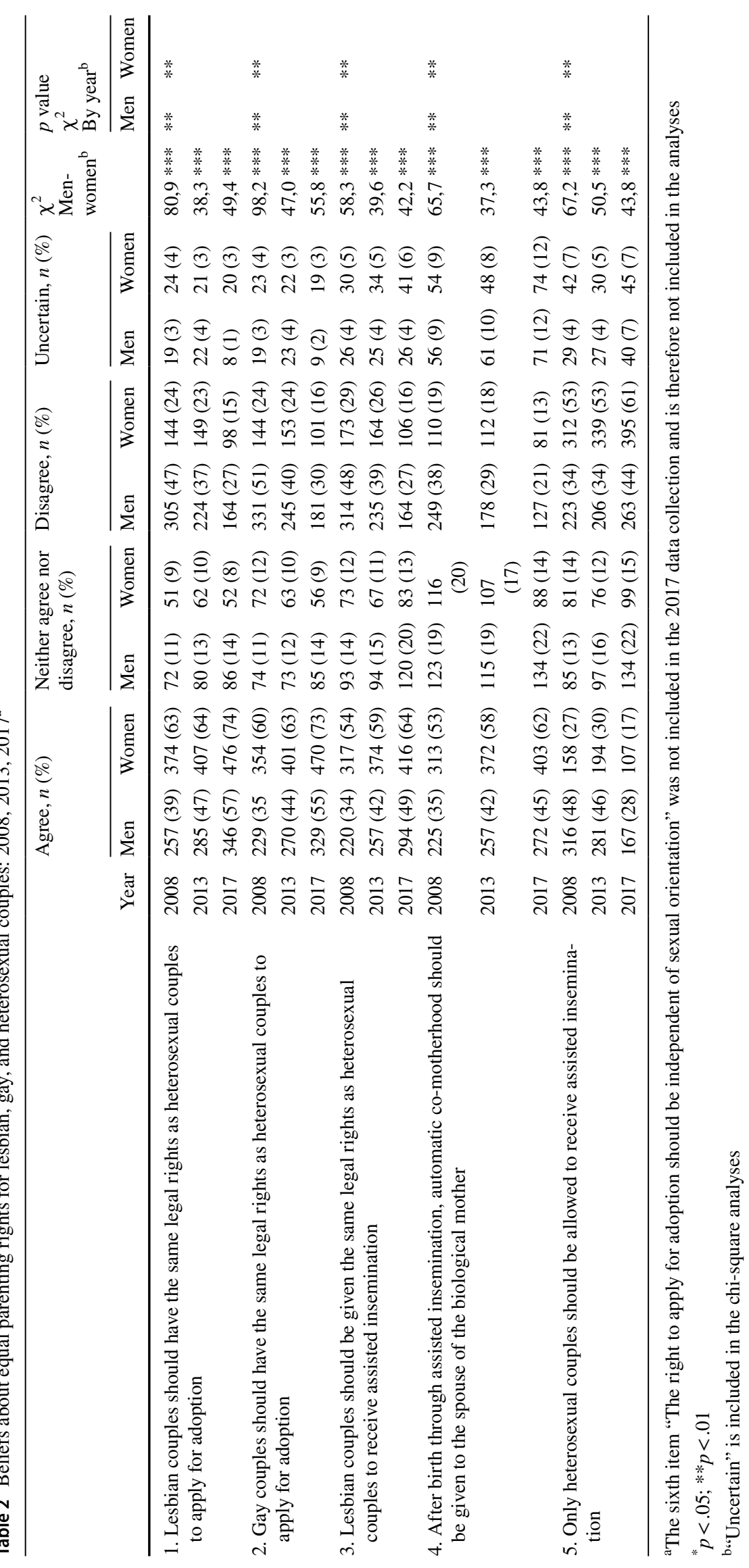


four items expressed concerns about the welfare of children with lesbian and gay parents, with the same response alternatives as for parenting rights (Table 2). The items were summed for the scale "Concerns about the welfare of children with lesbian and gay parents" (reversing the appropriate items), with high scores indicating concern for the children's welfare. The scale had Cronbach's alpha values of 0.92 (2008), 0.94 (2013), and 0.91 (2017).

Beliefs About Equal Marriage Rights for Lesbian, Gay and Heterosexual Couples. This concept was assessed by three statements (see Table 4) with response alternatives identical to the statements about equal parenting rights (see above). Responses to these items were summed for the scale "Beliefs about equal marriage rights for lesbian, gay and heterosexual couples," with high scores indicating positive attitudes. The scale had Cronbach's alpha values of 0.89 (2008), 0.89 (2013), and 0.85 (2017).

Demographics. Demographics included gender (coded as $\operatorname{man}=0$, woman $=1$ ), age, population density (recoded into $u r b a n=0$ and rural $=1$ ), education (primary/elementary and lower sec. school $=1$, upper second. school $=2$, univ./ college $=3$, univ./college higher degree $=4$ ), parental status (number of children), and religious faith. Religious faith was assessed by asking, "If you think about your relationship to the religion you belong to, where would you place yourself?" with response alternatives ranging from 1 (not believing) to 7 (believing). Response alternatives 1 and 2 were coded as "No or low faith," response alternatives 3 to 5 were coded as "Some faith," and response alternatives 6 and 7 were coded as "High faith." For each background question, the participants had the opportunity to respond that they did not wish to answer, and such responses were recoded as missing.

\section{Data Analyses}

Beliefs about parenting and marriage rights and about the welfare of children with gay and lesbian parents were displayed with cross-tabulations by gender and year of data collection. For the presentation of each item, the response alternatives "Completely agree" and "Slightly agree" were recoded as "Agree," and "Slightly disagree" and "Completely disagree" were recoded as "Disagree." Differences between women and men and between years of data collection were assessed with chi-square tests. Differences in mean values of the three scales (between gender in each data collection, and across years for each gender) were assessed with $t$ - and $F$-tests. F-tests and post-hoc analyses were conducted were conducted to compare demgraphic profiles of the three samples. Cross-tabulations with chi-square testing were used to assess the impact of selected background variables. The three scale sum-scores were correlated (Pearson's $r$ ). Finally, we conducted three hierarchical multiple regression analyses (one for each year of data collection; no dummy coding) to examine predictors of beliefs about equal parenting rights for lesbian, gay, and heterosexual couples. Step 1 included demographic variables (gender, age, population density, education, parental status, and religious faith), and step 2 included sum score of beliefs about the welfare of children with lesbian and gay parents. The SPSS program version 25 was used for the statistical analysis (Pallant, 2007).

\section{Results}

\section{Beliefs About Equal Parenting Rights}

The distribution of responses to the five items about equal parenting rights is displayed in Table 2. Among men, chi-square analyses of the response distribution for each item across the three data collections were statistically significant. Looking at the proportions for each item who responded with being negative, there was a decline in the proportion who disagreed that same-sex couples should be granted the same parental rights as heterosexual couples. Correspondingly, among women, there was a decline, mostly from 2013 to 2017. For example, for the item "Lesbian couples should have the same legal rights as heterosexual couples to apply for adoption," the disagree proportions among men were $47 \%, 37 \%$, and $27 \%$ in 2008,2013 , and 2017, respectively. Figure 1 shows the mean scores on the parental rights items, including the positive response categories. Women compared to men held significantly more positive beliefs regarding same-sex parenting rights at all three data collections (in $2008 \mathrm{t}(1081)=7.01, p<0.001$; in $2013 \mathrm{t}(1100)=6.88, p<0.001$; in $2017 \mathrm{t}(1059)=7.95$, $p<0.001)$. For men across time, mean scores were significantly different $(F(2,1615)=33.07, p<0.001)$, and LSD post hoc analyses showed that the difference between 2008-2013 and 2013-2017 were significantly different as shown in the figure. Among women, the changes across time were significant $(F(2,1632)=18.39 p<0.001)$, while LSD post hoc tests revealed that the only significant change was between 2013 and 2017 (2008-2013, $p=0.481,2013-2017$, $p<0.001)$.

\section{Beliefs About the Welfare of children with Lesbian and Gay Parents}

Responses to the eight items are presented in Table 3. Again, there was a decline in disagreement proportions from 2008 to 2013 to 2017 both among men and women, though more gradual among men. Additionally, the disagreement proportions were higher among men than among women. Figure 2 shows the mean sum-scores for men and women (including the agree-responses in the calculations). Women 


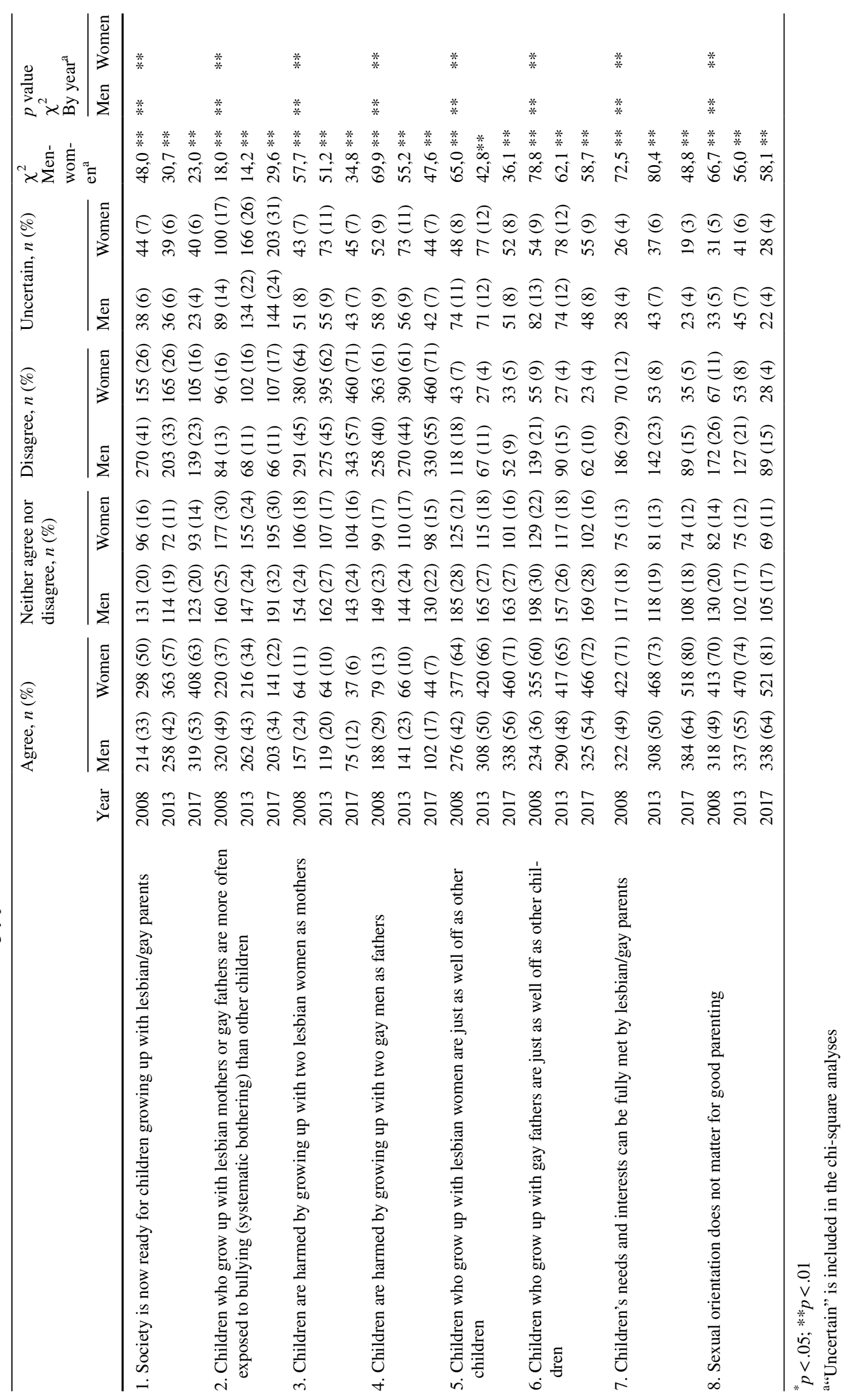




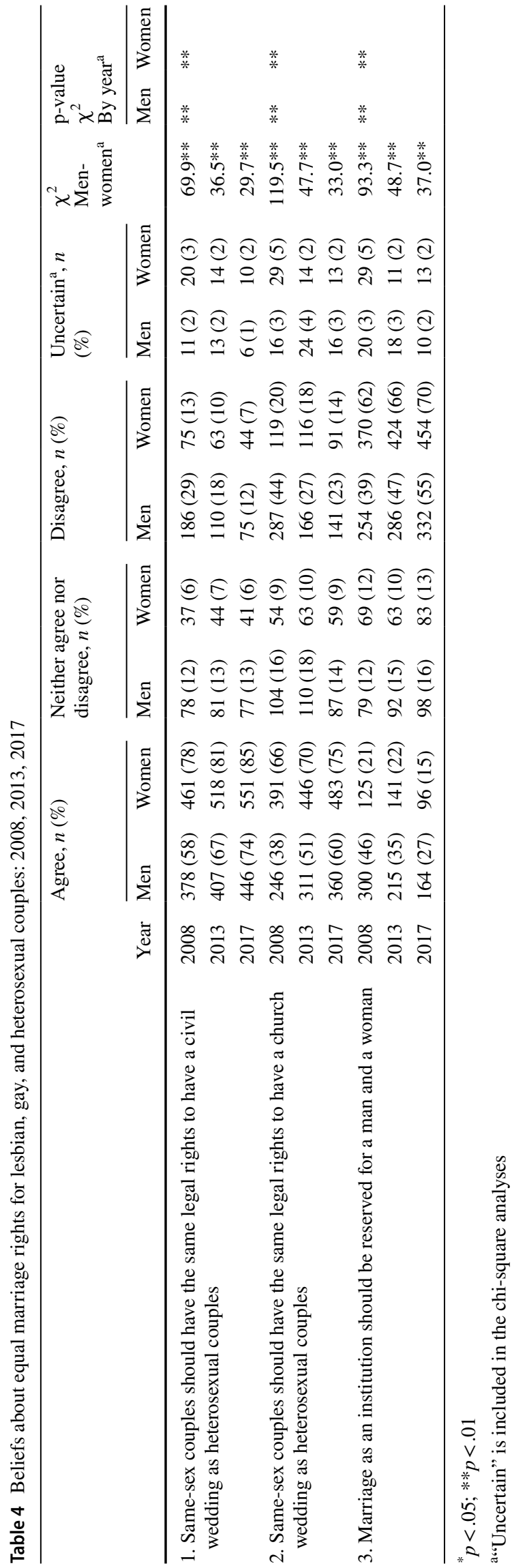

held significantly more positive beliefs at each year of data collection compared to men $(2008 t(911)=9.48, p<0.001$; $2013 t(815)=8.09, p<0.001 ; 2017 t(808)=8.51, p<0.001)$. The variation of mean scores for men across time was significant $(F(2,1312)=20.70, p<0.001)$, and LSD post hoc tests showed that the differences between means scores at each data collection also was significant (2008-2013, $p=0.001 ; 2013-2017, p=0.002)$. The variation across time among women had the same pattern. The overall variation was significant $(F(2,1262)=10.69, p=0.000)$ and LSD post hoc tests showed that the differences was significant between each data collection $(2008-2013, p=0.033 ; 2013-2017$, $p=0.013)$.

\section{Beliefs About Equal Marriage Rights}

Responses to three items on equal marriage rights are displayed in Table 4. Proportions who disagree that lesbian and gay couples have equal marriage rights decreased across the three data collection points, and the disagreement proportions were higher among men compared with women. Figure 3 shows the mean sum-scores for men and women (including the agree-responses in the calculations). Compared to men, women held significantly more positive beliefs about equal marriage rights in each data collection $(2008 t(1171)=11.13, p<0.001 ; 2013 t(1193)=7.41$, $p<0.001 ; 2017 t(1202)=7.35, p<0.001)$. Among men, the overall variation in mean scores were significant $(F(2,1784)=42.19, p<0.001)$, and LSD post hoc tests revealed significant differences between years of data

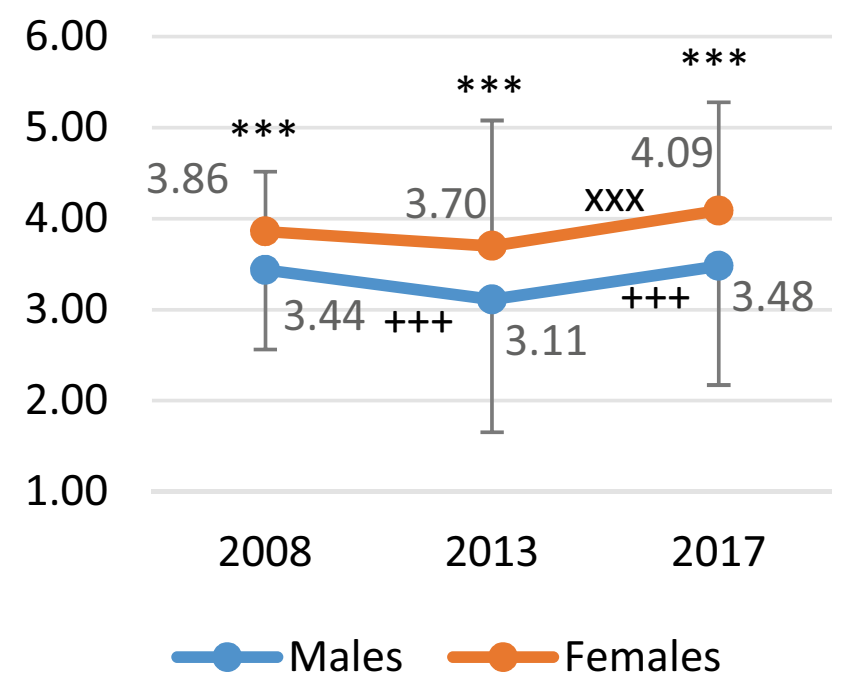

Fig. 1 Mean scores on beliefs about parenting rights items ${ }^{\mathrm{a}}$. 1=Completely disagree, $5=$ Completely agree. ${ }^{\mathrm{a}} *=\mathrm{T}$-test differences between men and women, $* * * \mathrm{p}<.001 .+=$ LSD post-hoc test on differences across each year for men, $+++\mathrm{p}<0.001$. $\mathrm{x}=$ LSD post-hoc test on differences across each year for women, $\mathrm{xxx} p<0.001$ 


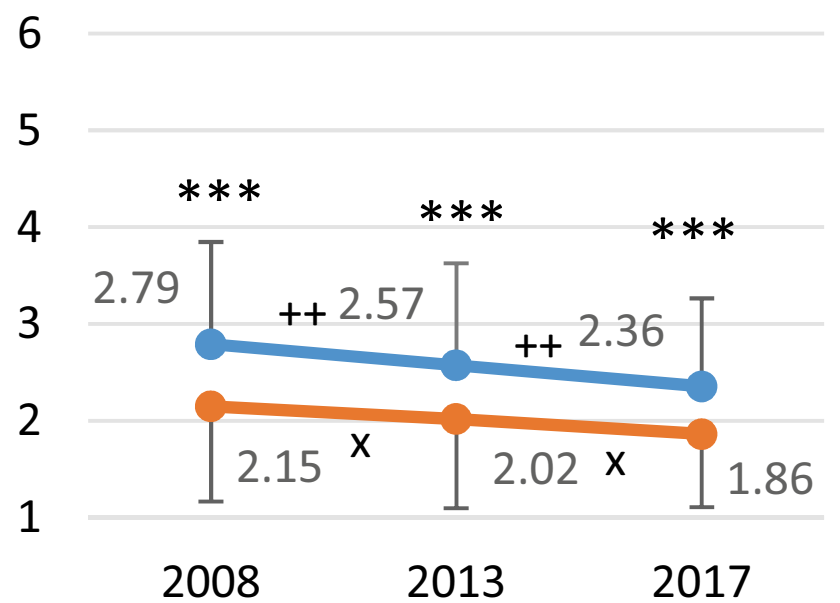

Males

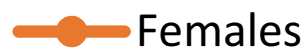

Fig. 2 Mean scores on beliefs about the welfare of children with same-sex parents items ${ }^{\mathrm{a}}$. $1=$ Completely disagree, 5=Completely agree. ${ }^{a} *=\mathrm{T}$-test differences between men and women, $* * * \mathrm{p}<.001 .+=$ LSD post-hoc test on differences across each year for men, $++\mathrm{p}<01 . \mathrm{x}=\mathrm{LSD}$ post-hoc test on differences across each year for women, $\mathrm{x} \mathrm{p}<.05$

collection (2008-2013, $p<0.001 ; 2013-2017, p=0.001)$. Among women, the overall variation was significant $(F(2,1786)=10.20, p<0.001)$, while LSD post hoc tests revealed that only the difference between 2013 and 2017 was significant (2008-2013, $p=0.076 ; 2013-2017, p=0.006)$.

\section{Demographics and Beliefs About Equal Parenting Rights}

Table 5 shows the proportions of participants who expressed negative beliefs towards equal parental rights in at least 4 out of 5 questions at each data collection point. Regarding age groups, at each data collection point and among both men and women, significantly more older participants -60 years and above-reported negative beliefs. There was no clear tendency comparing urban and rural respondents at each data collection point. Among men, significantly more rural respondents reported negative beliefs in 2017 (15\% vs. $11 \%$ ), but not so in 2008 and 2013, and among women, significantly more rural respondents reported negative beliefs in 2013 (28\% versus 19\%), but not so in 2008 and 2017. In regard to parental status, at each data collection point and among men and women, significantly more participants with children reported negative beliefs (except for among women in 2008, where there was no significant difference). In regard to education, in 2017 , significantly more men with higher university degrees reported negative beliefs, while the picture was opposite among women; in

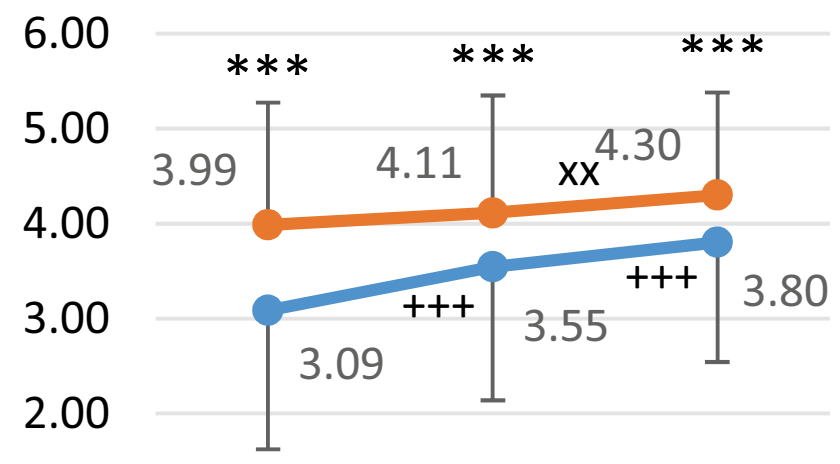

1.00

\section{$2008 \quad 2013 \quad 2017$}

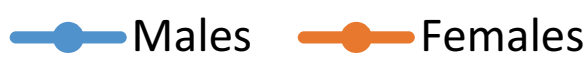

Fig. 3 Mean scores on beliefs about equal marriage rights for same-sex couples items ${ }^{\mathrm{a}}$. $1=$ Completely disagree, $5=$ Completely agree. ${ }^{\mathrm{a}}=\mathrm{T}$-test differences between men and women, $* * * \mathrm{p}<.001$. $+=$ LSD post-hoc test on differences across each year for men, $+++\mathrm{p}<.001$. $\mathrm{x}=$ LSD post-hoc test on differences across each year for women, $\mathrm{xx} \mathrm{p}<.010$

2008 and 2017, those with the least education reported significantly more negative beliefs. The clearest finding relates to religious faith: at each data collection point and among men and women, significantly more respondents with high religious faith reported negative beliefs about equal parenting rights.

\section{Conceptual Model}

Sum scores of the three scales were strongly correlated for men and for women at all three data collection points, with Pearson's $r$ varying between 0.57 and 0.82 in absolute values; all numbers were significant (see Table 6). To reduce any collinearity concerns, we decided to include only beliefs about the welfare of children as predictors for beliefs about equal parenting rights in the regression analyses. Three hierarchical multiple regression analyses were conducted to assess predictors of the belief that lesbian and gay couples should be granted the same legal rights to become parents as heterosexual couples. Gender, age, urban/rural status, being a parent, length of education, and religious faith were entered in the first step. In 2008, the background variables explained $11 \%$ of the variance (step 1). When concerns about the welfare of children with gay and lesbian parents were taken into consideration, the model explained $60 \%$ of the variance $[F(8797)=296.28, p=0.00]$ (see Table 7). Thus, step 2 explained an additional $49 \%$ of the variance in beliefs that lesbian and gay couples should be granted 
Table 5 Negative beliefs about equal parenting rights, stratified by selected background variable ${ }^{\mathrm{a}}$

\begin{tabular}{|c|c|c|c|c|c|c|}
\hline & \multicolumn{2}{|l|}{2008} & \multicolumn{2}{|l|}{2013} & \multicolumn{2}{|l|}{2017} \\
\hline & Men, $\%(n / N)$ & Women, \% $(n / N)$ & Men, \% $(n / N)$ & Women, \% $(n / N)$ & Men, $\%(n / N)$ & Women, \% $(n / N)$ \\
\hline Total sample & $30 \%(193 / 653)$ & $14 \%(258 / 593)$ & $33 \%(199 / 611)$ & $20 \%(127 / 639)$ & $20 \%(116 / 598)$ & $11 \%(73 / 641)$ \\
\hline \multicolumn{7}{|l|}{ Age (years) } \\
\hline $15-20$ & $8 \%(3 / 37)$ & $10 \%(7 / 72)$ & $0 \%(0 / 10)$ & $4 \%(1 / 24)$ & $0 \%(0 / 14)$ & $0 \%(0 / 19)$ \\
\hline $21-30$ & $19 \%(12 / 65)$ & $11 \%(16 / 145)$ & $16 \%(14 / 87)$ & $11 \%(10 / 95)$ & $6 \%(5 / 83)$ & $5 \%(6 / 113)$ \\
\hline $31-40$ & $24 \%(15 / 63)$ & $17 \%(24 / 138)$ & $28 \%(27 / 97)$ & $15 \%(17 / 111)$ & $21 \%(21 / 102)$ & $2 \%(2 / 90)$ \\
\hline $41-50$ & $30 \%(24 / 79)$ & $10 \%(13 / 126)$ & $33 \%(37 / 113)$ & $15 \%(15 / 99)$ & $15 \%(17 / 113)$ & $12 \%(14 / 121)$ \\
\hline $51-60$ & $28 \%(39 / 141)$ & $14 \%(9 / 66)$ & $33 \%(36 / 109)$ & $23 \%(28 / 122)$ & $22 \%(14 / 65)$ & $11 \%(11 / 104)$ \\
\hline $61-70$ & $37 \%(67 / 183)$ & $24 \%(8 / 33)$ & $47 \%(67 / 144)$ & $30 \%(41 / 138)$ & $26 \%(34 / 132)$ & $23 \%(31 / 137)$ \\
\hline $71-80$ & $39 \%(33 / 85)$ & $23 \%(3 / 13)$ & $37 \%(17 / 46)$ & $30 \%(14 / 47)$ & $28 \%(25 / 89)$ & $16 \%(9 / 57)$ \\
\hline $\begin{array}{l}\text { Chi-square } 15-59 \text { years vs. } 60 \\
\text { years or more }\end{array}$ & $9.73 * *$ & $6.18 * *$ & $18.70 * *$ & $28.45^{* *}$ & $24.14 * *$ & $30.46^{* *}$ \\
\hline \multicolumn{7}{|l|}{ Population density ${ }^{\mathrm{c}}$} \\
\hline Urban & $29 \%(161 / 551)$ & $13 \%(65 / 510)$ & $31 \%(156 / 500)$ & $19 \%(100 / 542)$ & $19 \%(96 / 505)$ & $11 \%(62 / 555)$ \\
\hline Rural & $32 \%(32 / 99)$ & $17 \%(13 / 76)$ & $39 \%(43 / 111)$ & $28 \%(27 / 97)$ & $23 \%(22 / 94)$ & $15 \%(12 / 82)$ \\
\hline Chi-square $^{\mathrm{b}}$ & $1.68(p=.80)$ & $4.57(p=.33)$ & $2.81(p=.25)$ & $6.10^{*}$ & $10.81^{*}$ & $4.70(p=.32)$ \\
\hline \multicolumn{7}{|l|}{ Parental status } \\
\hline Has children & $35 \%(168 / 481$ & $14 \%(49 / 350)$ & $37 \%(150 / 405)$ & $23 \%(102 / 449)$ & $23 \%(92 / 398)$ & $15 \%(63 / 423)$ \\
\hline No children & $15 \%(25 / 172)$ & $13 \%(31 / 243)$ & $24 \%(49 / 206)$ & $13 \%(25 / 190)$ & $13 \%(27 / 206)$ & $5 \%(11 / 223)$ \\
\hline Chi-square ${ }^{\mathrm{b}}$ & $25.47 * *$ & $4.37(p=.11)$ & $14.00 * *$ & $20.90 * *$ & $10.62 *$ & $27.19 * *$ \\
\hline \multicolumn{7}{|l|}{ Education } \\
\hline $\begin{array}{l}\text { Primary/elementary, lower sec. } \\
\text { school }^{\mathrm{d}}\end{array}$ & $27 \%(19 / 70)$ & $26 \%(14 / 55)$ & $26 \%(12 / 46)$ & $26 \%(11 / 42)$ & $18 \%(9 / 49)$ & $22 \%(10 / 45)$ \\
\hline Upper second. school & $29 \%(52 / 180)$ & $14 \%(30 / 211)$ & $29 \%(46 / 161)$ & $21 \%(38 / 181)$ & $22 \%(37 / 167)$ & $14 \%(30 / 213)$ \\
\hline Univ./college & $31 \%(86 / 276)$ & $11 \%(25 / 227)$ & $36 \%(97 / 267)$ & $19 \%(54 / 285)$ & $16 \%(42 / 256)$ & $11 \%(28 / 258)$ \\
\hline Univ./college higher degree & $29 \%(35 / 122)$ & $12 \%(11 / 91)$ & $32 \%(42 / 132)$ & $17 \%(20 / 119)$ & $24 \%(29 / 122)$ & $3 \%(4 / 121)$ \\
\hline Chi-square $^{b}$ & $4.95(\mathrm{p}=.763)$ & $16.67 *$ & $13.98(\mathrm{p}=.08)$ & $7.20(\mathrm{p}=.51)$ & $21.88^{*}$ & $22.48^{*}$ \\
\hline \multicolumn{7}{|l|}{ Religious faith } \\
\hline No or low faith & $21 \%(73 / 344)$ & $7 \%(21 / 319)$ & $25 \%(87 / 350)$ & $14 \%(40 / 295)$ & $15 \%(48 / 331)$ & $4 \%(12 / 74)$ \\
\hline Some faith & $29 \%(25 / 87)$ & $14 \%(11 / 79)$ & $28 \%(22 / 78)$ & $20 \%(20 / 102)$ & $13 \%(9 / 69)$ & $10 \%(9 / 87)$ \\
\hline High faith & $44 \%(90 / 206)$ & $25 \%(46 / 187)$ & $49 \%(85 / 174)$ & $28 \%(62 / 219)$ & $31 \%(59 / 188)$ & $22 \%(49 / 220)$ \\
\hline Chi-square ${ }^{\mathrm{b}}$ & $39.28 * *$ & $43.00 * *$ & $56.28 * *$ & $46.13^{* *}$ & $53.43 * *$ & $87.85^{* *}$ \\
\hline
\end{tabular}

${ }^{*} p<.05 ; * * p<.01$

${ }^{\text {a }}$ Participants reported being negative towards at least 4 out of 5 questions, concerning attitudes towards gay and lesbian couples being granted the same legal rights to become parents as heterosexual couples

${ }^{\mathrm{b}}$ Comparing responses among men and among women, separately

cResponses originally "Oslo," "Bergen, Stavanger Trondheim," "City with 20,000-100,000 inhabitants," "City or town with <20,000 inhabitants," and "Sparsely populated area." The latter response alternative was recoded into "Rural" and the four former alternatives into "Urban"

${ }^{\mathrm{d}}$ This response was originally two separate questions (7 years of school and 9 or 10 years of school)

the same legal rights to become parents as heterosexual couples. Correspondingly, in 2013 the model explained $71 \%$ of the variance (step 2 added 54\%), and in 2017, the model explained $63 \%$ of the variance (step 2 added $44 \%$ ). The same two variables were significant across the data collections (age and concerns about the welfare of children). Population density, being a parent, and educational achievement did not add significantly to the model at any data collection point.

\section{Discussion}

In this analysis, we compared public beliefs on same-sex parenting rights and related concerns in 2008, 2013, and 2017 in Norway, the 10-year period immediately following the Norwegian gender-neutral Marriage Act's adoption. The period was characterized by a shift toward fewer people holding negative beliefs about lesbian and gay 
Table 6 Pearson's $r$ correlations between the three scales ${ }^{\mathrm{a}}$

\begin{tabular}{llllllr}
\hline & Year & \multicolumn{2}{l}{ Welfare of children } & \multicolumn{2}{l}{$\begin{array}{l}\text { Equal marriage } \\
\text { rights }\end{array}$} \\
\cline { 3 - 4 } \cline { 5 - 6 } & & Men & Women & & Men & Women \\
\hline $\begin{array}{l}\text { Equal parenting } \\
\text { rights }\end{array}$ & 2008 & -0.76 & -0.75 & & 0.67 & 0.57 \\
& 2013 & -0.82 & -0.82 & 0.77 & 0.74 \\
& 2017 & -0.76 & -0.77 & & 0.79 & 0.80 \\
$\begin{array}{l}\text { Welfare of } \\
\text { children }\end{array}$ & 2008 & & & -0.74 & -0.65 \\
& 2013 & & & & -0.78 & -0.76 \\
& 2017 & & & -0.71 & -0.71 \\
\hline
\end{tabular}

${ }^{\mathrm{a}}$ For all numbers, $\mathrm{p}<0.001$

family rights and less public concern about the welfare of children growing up in same-sex families. Simultaneously, we observed stability across time on variables explaining beliefs about same-sex family rights - age and beliefs about the welfare of children with same-sex parents (in 2013 and 2017 religious faith contributed significantly, and in 2017 also gender contributed significantly).

\section{Change in Population Beliefs on Same-Sex Family Rights}

Over time, fewer people held negative beliefs about samesex family rights, including parental rights, concerns for the welfare of children with same-sex parents, and marriage rights for same-sex couples. This outcome is in line with developments we see in a number of countries (Cox et al., 2014; ILGA-Europe, 2019; Lipka, 2013). The decline was distinct among men, with approximately $10 \%$ fewer men with negative beliefs at each data collection point. Additionally, among women, there was a drop in proportions with negative beliefs from the first to the third data collection point, but not as strong and not as gradual as among men. This development means that the gap between male and female negative beliefs about same-sex family rights is closing in Norway. The gap observed in the period of 2008 to 2017 decreased by approximately $10 \%$ overall.

The decline in levels of negative beliefs about same-sex family rights may have resulted from long-term societal and structural processes such as continuous detraditionalization, secularization, and high levels of education (Hooghe \& Meeusen, 2013), which characterize Nordic countries such as Norway. Since the late 1980s, there has been, for example, a steady decline in membership to majority churches (Evangelical Lutheran) and an increase in those without a religious affiliation (Furseth, 2018). Changes have also gradually taken place within the Norwegian Church. For example, after heated debates, in 2017, the Norwegian
Church introduced a common wedding liturgy for same- and different-sex couples (Den norske kirke, 2017).

The decline may further be seen in light of historically rooted egalitarianism and individualization processes, which are characteristic of contemporary Norwegian society (Bendixen et al., 2018). A history of feminist activism, the Nordic "dismantling of explicitly patriarchal marriage" (Therborn, 2004, p. 80), "state commitment to gender equality" (Roseneil et al., p. 167), and a strong and long-standing discourse on children as subjects of their own individual rights (Gullestad, 1997) are all part of a Norwegian legacy. In 2003 and 2009, respectively, the Convention on the Rights of the Child and the Convention on the Elimination of all Forms of Discrimination against Women were included in the Norwegian Human Rights Law (1999). Individual rights for children are now also included in the Norwegian Constitution (2014). The Human Rights Law in Norway has a strong standing, as it has priority in cases of conflict with other domestic laws. Importantly, the Equality and Anti-discrimination Act (2017) (in effect from January 1, 2018, and replacing a number of earlier laws regulating this field) cites in its preamble the protection of LGBTI rights - sexual orientation, gender identity, and gender expression are now specified alongside issues of ethnicity and religion. Particular processes of normative change in Norwegian society, hand-in-hand with lawmaking, have most likely paved the way for securing LGBTI rights and have continuously increased acceptance of a variety of family forms and living arrangements (Roseneil et al., 2013). Norway scored high on equality and freedom of choice across various fields in 2017, 2018 and 2019 and was rated second on a yearly barometer of public opinion on gender equality, the Global Gender Gap Report (World Economic Forum, 2019).

While recognizing that the exact relationship between attitudes and law "remains opaque," it is increasingly acknowledged that these two phenomena are partly dependent on each other (Kenny \& Patel, 2017, p. 1). Research supports the claim that legal relationship recognition is associated with an increase in positive attitudes toward sexual minorities (Abou-Chadi \& Finnigan, 2018; Takács et al., 2016) and across demographic groups (Aksoy et al.,). Aksoy et al. (2018) state that in the realm of sexual minorities, law is a powerful instrument in shaping societal attitudes. Likewise, Kreitzer et al. (2014) claim that their findings lend general support for "policy feedback as applied to morality policy" (p. 805). While there is a long way to go from enacting legislation to full implementation and utilization (the eradication of discrimination) (Roseneil et al., 2013), there is reason to suggest that clear normative messages from the state do have a long-term socialization effect in relation to increased acceptance of same-sex family rights (Takács et al., 2016). 
Table 7 Hierarchical multiple regression analysis of beliefs about equal parental rights for lesbian, gay and heterosexual couples, by year of data collection

\begin{tabular}{|c|c|c|c|c|c|}
\hline & $R^{2}$ & Adj. $R^{2}$ & $R^{2}$ change & $\mathrm{B}(\mathrm{SE} B)$ & Beta \\
\hline \multicolumn{6}{|l|}{2008} \\
\hline Step 1 & 0.11 & 0.11 & - & & \\
\hline Constant & & & & $18.73(0.53)$ & \\
\hline Gender $^{\mathrm{a}}$ & & & & $-2.00(0.30)$ & $-0.25 * * *$ \\
\hline Age & & & & $-0.01(0.01)$ & $-0.06(p=.206)$ \\
\hline Population density ${ }^{\mathrm{b}}$ & & & & $-0.03(0.39)$ & $-0.01(p=.950)$ \\
\hline Being parent ${ }^{\mathrm{c}}$ & & & & $-0.17(0.35)$ & $-0.01(p=.634)$ \\
\hline Education $^{\mathrm{d}}$ & & & & $0.72(0.28)$ & $0.11^{* *}$ \\
\hline Religious faith ${ }^{\mathrm{e}}$ & & & & $-0.71(0.15)$ & $-0.20 * * *$ \\
\hline Step 2 & 0.61 & 0.60 & 0.50 & & \\
\hline Constant & & & & $26.64(0.50)$ & \\
\hline Gender $^{\mathrm{a}}$ & & & & $0.21(0.23)$ & $0.26(p=.373)$ \\
\hline Age & & & & $-0.02(0.01)$ & $-0.08 *$ \\
\hline Population density ${ }^{\mathrm{b}}$ & & & & $-0.06(0.29)$ & $-0.01(p=.834)$ \\
\hline Being parent ${ }^{c}$ & & & & $0.17(0.27)$ & $0.02(p=.540)$ \\
\hline Education $^{\mathrm{d}}$ & & & & $0.14(0.11)$ & $0.02(p=.549)$ \\
\hline Religious faith $^{\mathrm{e}}$ & & & & $-0.13(0.05)$ & $-0.04(p=.106)$ \\
\hline Beliefs, welfare of children ${ }^{\mathrm{f}}$ & & & & $-0.44(0.02)$ & $-0.75 * * *$ \\
\hline \multicolumn{6}{|l|}{2013} \\
\hline Step 1 & 0.17 & 0.17 & - & & \\
\hline Constant & & & & $23.27(0.78)$ & \\
\hline Gender $^{\mathrm{a}}$ & & & & $3.12(0.41)$ & $0.22 * * *$ \\
\hline Age & & & & $-0.08(0.01)$ & $-0.18 * * *$ \\
\hline Population density ${ }^{\mathrm{b}}$ & & & & $-0.82(0.55)$ & $-0.04(p=.131)$ \\
\hline Being parent ${ }^{c}$ & & & & $-0.89(0.50)$ & $-0.06(p=.070)$ \\
\hline Education $^{\mathrm{d}}$ & & & & $0.26(0.42)$ & $0.02(p=.538)$ \\
\hline Religious faith $^{\mathrm{e}}$ & & & & $-1.72(0.22)$ & $-0.23^{* * *}$ \\
\hline Step 2 & 0.71 & 0.71 & 0.54 & & \\
\hline Constant & & & & $32.79(0.58)$ & \\
\hline Gender $^{\mathrm{a}}$ & & & & $0.38(0.29)$ & $0.03(p=.187)$ \\
\hline Age & & & & $-0.03(0.01)$ & $-0.07 * * *$ \\
\hline Population density ${ }^{\mathrm{b}}$ & & & & $-0.19(0.38)$ & $-0.01(p=.614)$ \\
\hline Being parent ${ }^{\mathrm{c}}$ & & & & $-0.26(0.34)$ & $-0.02(p=.451)$ \\
\hline Education $^{\mathrm{d}}$ & & & & $-0.44(0.29)$ & $-0.03(p=.129)$ \\
\hline Religious faith $^{\mathrm{e}}$ & & & & $-0.52(0.16)$ & $-0.07 * * *$ \\
\hline Beliefs, welfare of children ${ }^{f}$ & & & & $-0.68(0.02)$ & $-0.80 * * *$ \\
\hline \multicolumn{6}{|l|}{2017} \\
\hline Step 1 & 0.19 & 0.19 & - & & \\
\hline Constant & & & & $24.02(0.64)$ & \\
\hline Gender $^{\mathrm{a}}$ & & & & $2.75(0.34)$ & $0.23 * * *$ \\
\hline Age & & & & $-0.07(0.01)$ & $-0.19 * * *$ \\
\hline Population density ${ }^{\mathrm{b}}$ & & & & $-0.09(0.49)$ & $-0.01(p=.859)$ \\
\hline Being parent ${ }^{\mathrm{c}}$ & & & & $-0.30(0.43)$ & $-0.02(p=.482)$ \\
\hline Education $^{\mathrm{d}}$ & & & & $0.89(0.35)$ & $0.07 *$ \\
\hline Religious faith $^{\mathrm{e}}$ & & & & $-1.62(0.18)$ & $-0.26 * * *$ \\
\hline Step 2 & 0.63 & 0.63 & 0.44 & & \\
\hline Constant & & & & $32.13(0.57)$ & \\
\hline Gender $^{\mathrm{a}}$ & & & & $0.56(0.28)$ & $0.05^{*}$ \\
\hline Age & & & & $-0.04(0.01)$ & $-0.10 * * *$ \\
\hline Population density ${ }^{\mathrm{b}}$ & & & & $-0.02(0.38)$ & $-0.00(p=.961)$ \\
\hline Being parent ${ }^{\mathrm{c}}$ & & & & $-0.35(0.34)$ & $-0.03(p=.307)$ \\
\hline
\end{tabular}


Table 7 (continued)

\begin{tabular}{|c|c|c|c|}
\hline$R^{2}$ & $R^{2}$ change & B (SE B) & Beta \\
\hline Education $^{\mathrm{d}}$ & & $0.43(0.27)$ & $0.04(p=.116)$ \\
\hline Religious faith ${ }^{\mathrm{e}}$ & & $-0.42(0.15)$ & $-0.07 * * *$ \\
\hline Beliefs, welfare of children ${ }^{\mathrm{f}}$ & & $-0.61(0.02)$ & $-.73 * * *$ \\
\hline \multicolumn{4}{|l|}{$* p<.05 ; * * p<.01 ; * * * p<.001$} \\
\hline \multicolumn{4}{|l|}{${ }^{\mathrm{a}}$ Male $=0$, female $=1$} \\
\hline \multicolumn{4}{|l|}{${ }^{\mathrm{b}}$ Urban $=0$, rural $=1$} \\
\hline \multicolumn{4}{|l|}{${ }^{\mathrm{c}}$ Not a parent $=0$, Being a parent $=1$} \\
\hline \multicolumn{4}{|c|}{${ }^{\mathrm{d}}$ Less than college degree $=0$, College degree or higher $=1$} \\
\hline${ }^{\mathrm{e}}$ Higher number, stronger faith & & & \\
\hline${ }^{\mathrm{f}}$ Higher number means more concern fo & Iren's welfare & & \\
\hline
\end{tabular}

Roseneil et al. (2013), in studying transformation in institutional norms about same-sex sexualities across four countries, highlight another Norwegian national-specific normative trait that they claim may have additionally compelled increased tolerance and normalization in Norway. The authors suggest that the Norwegian willingness to seek reform "in the realm of intimate citizenship" can also be understood in light of a tradition of long and close connections between the state and various activists/activist organizations (for example, the women's movement) (Roseneil et al., 2013, p. 184). This was something the lesbian and gay movement was able to take advantage of. The lesbian and gay movement "was able to attach itself to hallowed Norwegian values of equality, gender equality [likestilling] and inclusion," perhaps with greater ease than in many other countries (Roseneil et al., 2013, p. 184).

\section{Stability Across Time in Relationships Between Variables}

Not unexpectedly, there was some stability across time on factors explaining beliefs about lesbian and gay family rights. More men than women disagreed on granting same-sex couples equal parenting and marriage rights. Consistently, men were more concerned about the welfare of children growing up with same-sex parents in 2008, 2013 and 2017. Furthermore, for men and women and across the three data collection points, negative beliefs about equal parental rights were stronger than beliefs about equal marriage rights. When assessing predictors of beliefs that same-sex and heterosexual couples should have the same legal rights to become parents, beliefs about the welfare of children in same-sex families continued to explain most of the variance: $49 \%, 54 \%$, and $44 \%$ in 2008,2013 , and 2017 , respectively. Among the demographic variables, age (being older) added to the explained variance at all three points of data collection, while faith (stronger) added to the explained variance in 2013 and 2017.
The stability may reflect a stable conservatism factor in the data-older (in 2013 and 2017) more religious participants held more negative attitudes toward samesex family rights. However, more fundamentally, stability may reflect deep-rooted patterns of heteronormativity, i.e., notions that existing arrangements are good: a binary gender system in which each gender is naturally sexually attracted to the other gender (e.g., Herek, 2004; Ingraham, 1994). Heteronormativity has historically firmly established notions about family life and family politics and what may be considered acceptable families and parenthood (Ohnstad, 2008). Same-sex parenting challenges gender norms and norms regulating sexuality and reproductionwhat constitutes a family and the position of the child-as we know them. Granting same-sex couples parental rights may be experienced as challenging the "natural order" and, in particular, "the symbolic order of the family" (Lasio \& Serri, 2017, pp. 692,704). Related to this notion, children and children's welfare quickly become a pivot in the samesex family rights debate (Hollekim et al., 2015).

\section{LGBTI Rights as Markers for Other Values?}

The findings provide a picture of continuously fewer negative beliefs on same-sex parenting rights and increasingly less concern for children in same-sex families. LGBTI rights have acquired increasingly important symbolic public value in Norway and Europe (Jakobsen, 2018; Slootmaeckers et al., 2016). This points to a need to direct attention toward how the findings may be interpreted within a broader framework in relation to new landscapes of political and public discourse in Norway and Europe. Røthing and Bang Svendsen (2010) claim that "equality between homosexual and heterosexual relationships has increasingly been presented as a marker for Norwegian values" (2010, p 147). Roseneil et al. (2013) also point to how support for gender equality and LGBTI rights has "come to be seen as characteristically "Norwegian"” (p. 184). For example, 
in the public discourse on immigration, tolerance toward sexual minorities is used to distinguish between a preferred Norwegian culture as opposed to non-Western cultures and, more so, Muslim cultures (Gressgård \& Jacobsen, 2008; Mühleisen et al., 2012). Gressgård and Jacobsen (2008) argue that "calls for tolerance towards homosexuals produce and position subjects and identities" and mark opposition between "the liberal and illiberal- 'us' and 'the others"" (p. 39). Gender and sexuality equality have become constitutive for Norwegian identity, "produced in relation to the Other either internal (immigrant, Muslim) or external (foreign, non-Western)" and becoming "crucial to the understanding of Norwegian society as a community of value" (Jakobsen, 2018, p. 313). Similarly, Bang Svendsen (2014), in studying the political debate around sexuality and race in Norway in the years since 2000, claims that important dividing lines between radicals and conservatives (traditional and Christian values) have become less pronounced. At present, queer political arguments are sometimes seen used as anti-Muslim arguments in Norwegian public debate. In studying textbooks used in Norwegian schools, Røthing and Bang Svendsen (2010) found that "Norwegian sexual norms appear to be self-evident, modern, progressive, and equal", while sexual norms of "others" may appear to be "as evidently pre-modern, under-developed, and oppressive" (p. 153).

Interestingly, we have also seen the same symbolic self-presentation concerning the position of the child in Norwegian society. Findings showing less concern for children within same-sex families may be linked to the same processes based on an increasingly established notion that lesbian and gay parents are similar to "us" (Hollekim et al., 2015) and consequently provide less reason for concern regarding their children. The special value given to children as autonomous and equal individuals has frequently been discussed "with regard to national symbolism and self-image as a way through which this country presents itself as an egalitarian, young, democratic peaceful and innocent nation" (Arias et al., 2020, p. 2; Hennum, 2017; Satka \& Eydal, 2004).

The symbolic value of LGBTI rights is also evident in EU politics and discourse. Slootmaeckers et al. (2016) claim that in this impact area, in some EU countries, we see a domestic national identity discourse "that links nationalism with political homophobia" (p. 4). While the European Parliament resolution of 2006 clearly states that LGBTI people shall enjoy the same respect, dignity and protection as all other citizens, there are indications of increased polarization on these questions (Ayob, 2014; Kulpa, 2013; Slootmaeckers et al., 2016). National forces are using this impact area to draw boundaries between "the decadent West" and "the traditional East" (Slootmaeckers et al., 2016, p. 4). Ayoub (2014) argues, for example, that in Poland, "domestic opposition has succeeded in framing a narrative that linked LGBTI rights to external forces threatening national values" (p. 337). In mirroring similar processes within other morally laden fields, namely, the position of the child as a subject of his/her own individual rights, Holm-Hansen $(2017,2020)$ discussed the strong and continued protests against Norwegian Child Welfare Services (NCWS) from, in particular, Eastern European countries (Hennum, 2017). He suggests that such protest may be understood against the same political backdrop, a political landscape characterized by a fight between "inwardlooking", lifestyle conservative ways of thinking on one side and more progressive, "open-to-the world" directions on the other. When NCWS, for example, takes children into care against a family's wishes, this act is typically narrated as an attack on the nation of origin, the "family" and "traditional" (patriarchal) family ideals and values. This debate links to the LGBTI debate, where, for example, Takács et al. (2016) claim that fierce opposition against same-sex adoption rights typically originates from a fear of an acceptance of broader family definitions and new types of families. According to Holm-Hansen $(2017,2020)$, this development has broader ramifications, typically expressed through the concept of "gender." The "gender" concept is, according to him, a collective term that refers to anything from elective abortion to equal pay, the prohibition of family violence, acceptance of lesbians and gays and the Convention of the Rights of the Child, and importantly, forced upon the East by the West. Superior, Makarychev and Medvedev (2015), in studying biopolitics and power in Russia, claim that this particular discourse is part of an authoritarian force aiming to consolidate elites' own power and the political basis of their reign.

\section{Strengths and Limitations}

A strength of the study is its repeated assessment of beliefs across 9 years (three data collection points) with nationwide samples utilizing the same questionnaire phrases and for the first nine years following the introduction of the Norwegian gender-neutral Marriage Act (2009). It is also a strength that the samples were large and of similar size across the three data collection points, as is its composition with ordinary adult citizens. As the data collections addressed sensitive themes, a Web-based solution may have reduced social desirability in answers. While the questionnaire items were pilot tested (for face validity), they were not formally validated. Response options "Neither agree nor disagree" and "Uncertain" were provided with the questionnaire items, which may have affected the number of respondents choosing not to express an opinion on various issues. A limitation is some missing data across the three datasets, but we see no reason to believe these were systematic. Also, 
the analyses include many $t$ tests and ANOVAs, which we realize is increasing the likelihood of type I error.

\section{Social Policy Implications}

The results reveal contemporary supportive public opinion regarding LGBTI family rights. This provides lawmakers with a foundation for further institutionalizing LGBTI rights. Identified areas for improvement in Norway include, for example, the prevalence and documentation of hate crimes and a need for increased knowledge in educational institutions and institutions offering family support and counseling (ILGA-Europe, 2017). Supportive public opinion also gives the government a basis for formulating ambitious measures in the upcoming Action Plan following from the current LGBTI Action Plan: Safety, Diversity, Openness (2017-2020). We also believe there is a need for awareness about how LGBTI issues may enter into broader divisive sociopolitical processes.

\section{Conclusion}

In this paper, we aimed to explore change and stability in public beliefs on lesbian and gay family rights with a particular focus on same-sex parenting rights. The period in question runs from 2008 to 2017, starting from the point at which the Norwegian gender-neutral Marriage Act was in effect (from January 1, 2009). It is reasonable to suggest that decreasing negative beliefs about same-sex family rights in Norway must be understood in light of broader societal and structural processes such as detraditionalization, secularization, and individualization; Norway's broader human rights record; and in particular, the country's early legal same-sex relationship and family recognition policies.

Acknowledgements We want to thank Hilde Slåtten for taking part in the initial work on the questionnaire and scales and Øystein Holmelid for help with the statistical analyses.

Funding Open access funding provided by University of Bergen (incl Haukeland University Hospital).

Data Availability The data used are retrieved from "Holdninger til LHBT-personer 2008"," Holdinger til LHBT-personel 2013 "and" Holdninger tih LHBT-personer 2017." The data in anonymized form are provided by University of Bergen, Uni Research Health and The Norwegian Directorate for children, Youth and Family Affairs (Bufdir) through NSD-Norwegian Centre for Research Data AS. Neither University of Bergen, Uni Research Health, Bufdir or NSD are responsible for the analysis of data, or interpretations that are done here.

Open Access This article is licensed under a Creative Commons Attribution 4.0 International License, which permits use, sharing, adaptation, distribution and reproduction in any medium or format, as long as you give appropriate credit to the original author(s) and the source, provide a link to the Creative Commons licence, and indicate if changes were made. The images or other third party material in this article are included in the article's Creative Commons licence, unless indicated otherwise in a credit line to the material. If material is not included in the article's Creative Commons licence and your intended use is not permitted by statutory regulation or exceeds the permitted use, you will need to obtain permission directly from the copyright holder. To view a copy of this licence, visit http://creativecommons.org/licenses/by/4.0/.

\section{References}

Abou-Chadi, T., \& Finnigan, R. (2018). Rights for same-sex couples and public attitudes toward gays and lesbians in Europe. Comparative Political Studies, 52(6), 868-895. https://doi.org/ 10.1177/0010414018797947

Aksoy, C. G., Carpenter, C.C., DeHaas, R., \& Tran, K. (2018). Do laws shape attitudes? Evidence from same-sex relationship recognition policies in Europe (IZA DP No. 11743). https://ftp.iza.org/ dp11743.pdf

Anderssen, N., \& Slåtten, H. (2008). Holdninger til lesbiske, homofile menn, bifile kvinner og menn, og trans-personer (LHBTpersoner). En landsomfattende representativ spørreundersøkelse [Attitudes towards lesbian, gay, bisexual women and men, and transpersons. A nation- wide representative survey] (University of Bergen). https://bora.uib.no/bora-xmlui/bitstream/handle/1956/ 3071/Holdninger_til_lhbt-personer_rapport.pdf?sequence $=1 \&$ isAllowed $=\mathrm{y}$

Arias, R.H., Hollekim, R., \& Haukanes. H. (2020). Self-legitimation and sense-making of southern European parents' migration to Norway: the role of family aspirations. Population, Space \& Place, 26(8). https://doi.org/10.1002/psp.2362

Ayoub, P. M. (2014). With arms wide shut: threat perception, norm reception, and mobilized resistance to LGBT rights. Journal of Human Rights, 13(3), 337-362. https://doi.org/10.1080/ 14754835.2014.919213

Bang Svendsen, S. H. (2014, February 25). Den norske skolen reproduserer rasisme og kjønnssterotypier [Norwegian schools reproduces racism and gender sterotypes]. Kilden Kjønnsforskning. http://kjonnsforskning.no/nb/2014/02/dennorske-skolen-reproduserer-rasisme-og-kjonnsstereotypier

Bendixen, S., Bringslid, M.B., \& Vike, H. (2018). Introduction. In S. Bendiksen, M.B. Bringslid \& Vike, H. (Eds.), Egalitarianism in Scandinavia. Historical and contemporary perspectives (p. 1-44). PalgraveMacmillan.

Costa, P. A., Carneiro, F. A., Esposito, F., D’Amore, S., \& Green, R. J. (2018a). Sexual prejudice in Portugal: Results from the First Wave European Study on heterosexual's attitudes toward samegender marriage and Parenting. Sexuality Research and Social Policy, 15, 99-110. https://link.springer.com/article/10.1007/ s13178-017-0292-y

Costa, P. A., Pereira, H., \& Leal, I. (2018b). Through the lens of sexual stigma. Attitudes toward lesbian and gay parenting. Journal of GLBT Family Studies, 15(1), 58-75. https://www.tandfonline. com/doi/full/10.1080/1550428X.2017.1413474

Cox, D., Navarro-Rivera, J., \& Jones, R. P. (2014, February 26). A shifting landscape: A decade of change in American attitudes about same-sex marriage and LGBT issues (PRRI). https://www. prri.org/research/2014-lgbt-survey/2014-lgbt-survey/

Cox, L. (2014, July 15). Poll shows growing support for same-sex marriage. The Sydney Morning Herald. https://www.smh.com.au/ politics/federal/poll-shows-growing-support-for-samesex-marriage20140714-3bxaj.html 
Dotti Sani, G. M., \& Quaranta, M. (2020). Let them be, not adopt: General attitudes towards gays and lesbians and specific attitudes towards adoption by same-sex couples in 22 European countries. Social Indicators Research, 150, 351-373. https://link.springer. com/article/10.1007/s11205-020-02291-1

European Commission (2006, September). Eurobarometer 66-Public opinion in the European Union. European Commission. http://ec. europa.eu/public_opinion/archives/eb/eb66/eb66_en.pdf

European Social Survey (2010). Gays and lesbians free to live their lives as they wish. NSD. http://nesstar.ess.nsd.uib.no/webview/index. jsp? $\mathrm{v}=2 \&$ submode $=$ variable $\&$ study $=\mathrm{http} \% 3 \mathrm{~A} \% 2 \mathrm{~F} \% 2 \mathrm{~F} 129.177$. 90.83\%3A-1\%2Fobj\%2FfStudy $\% 2 \mathrm{FESS} 5 \mathrm{e} 03.4 \& \mathrm{gs}=$ undefined \& variable $=$ http $\% 3 \mathrm{~A} \% 2 \mathrm{~F} \% 2 \mathrm{~F} 129.177 .90 .83 \% 3 \mathrm{~A} 80 \% 2 \mathrm{Fobj} \%$ 2FfVariable\%2FESS5e03.4_V128\&mode=documentation\& top=yes

Equality and Anti-Discrimination Act (2017). Act relating to equality and a prohibition against discrimination (LOV-2017-06-16-51). https://lovdata.no/lov/2017-06-16-51

Flores, A. R., \& Barclay, S. (2016). Backlash, consensus, legitimacy, or polarization: The effect of same-sex marriage policy on mass attitudes. Political Research Quarterly, 69(1), 43-56. https://doi. org/10.1177/1065912915621175

Furseth, I., Ahlin, L., Ketola, K., Leis-Peters, A., \& Sigurvinsson, B. R. (2018) Changing religious landscapes in the Nordic countries. In I. Furseth (Ed.), Religious Complexity in the Public Sphere. Comparing Nordic Countries (p. 31-80). Palgrave Macmillan. https://doi.org/10.1007/978-3-319-55678-9_2

Gato, J., \& Fontaine, A. M. (2015). Attitudes toward adoption by same-sex couples: Effects of gender of the participant, sexual orientation of the couple and gender of the child. Journal of GLBT Family Studies, 12(1), 1-22. https://doi.org/10.1080/1550428X. 2015.1049771

Gressgård, R., \& Jacobsen, C. M. (2008). Krevende toleranse: Islam og homoseksualitet [Demanding tolerance: Islam and homosexuality]. Tidsskrift for kjønnsforskning, 2, 22-39.

Gross, M., Vecho, O., Gratton, E., D’Amore, S., \& Green, R. J. (2017). Religious affiliation, religiosity, and attitudes toward same-sex parenting. Journal of GLBT Family Studies, 14(3), 238-259. https://doi.org/10.1080/1550428x.2017.1326016

Gullestad, M. (1997). A passion for boundaries. Reflections on connections between the everyday lives of children and discourses on the nation in contemporary Norway. Childhood, 4(1), 19-42. https://doi.org/10.1177/0907568297004001002

Hennum, N. (2017). The Norwegian child protection services in stormy weather. Critical and Radical Social Work, 5(3), 319-334. https:// www.ingentaconnect.com/contentone/tpp/crsw/2017/00000005/ $00000003 / \operatorname{art} 00004$

Herek, G. M. (2004). Beyond "homophobia". Thinking about sexual prejudice and stigma in the twenty-first century. Sexuality Research \& Social Policy, 1(2), 6-24. https://lgbpsychology.net/ html/Beyond_Homophobia_2004.PDF2004.PDF

Hollekim, R., Slåtten, H., \& Anderssen, N. (2012). A nationwide study of Norwegian beliefs about same-sex marriage and lesbian and gay parenthood. Sexuality Research \& Social Policy, 9(1), 15-30. https://doi.org/10.1007/s13178-011-0049-y

Hollekim, R., Anderssen, N., \& Andenæs, A. (2015). Images of children in views on same-sex adoption rights. Journal of LGBT Family Studies, 11(3), 229-247. https://doi.org/10.1080/ 1550428X.2014.947462

Holm-Hansen, J. (2017, April 8). Hvorfor er norsk barnevern ute i hardt vær [Why is Norwegian child welfare so contested]. Dagbladet. www.dagbladet.no

Holm-Hansen, J. (2020, March 5). Det norske systemet er godt [The Norwegian system works well]. Forskning.no. https://forskning. no/barn-og-ungdom-velferdsstat/professor-sammenliker-norskbarnevern-med-andre-land--det-norske-systemet-er-godt/1649387
Hooghe, M., \& Meeusen, C. (2013). Is same-sex marriage legislation related to attitudes toward homosexuality? Trends in tolerance of homosexuality in European countries between 2002 and 2010. Sexuality Research and Social Policy, 10, 258-268. https://doi. org/10.1007/s13178-013-0125-6

ILGA-Europe (2019). Annual Review 2019. Rainbow-Europe. https:// www.ilga-europe.org/rainboweurope/2019

ILGA-Europe (2017). Country ranking. Rainbow-Europe. https://rainb ow-europe.org/country-ranking

Ingraham, C. (1994). The heterosexual imaginary. Sociological Theory, 12(22), 203-219.

Jakobsen, C. M. (2018). The (in)egalitarian dynamics of gender equality and homotolerance in contemporary Norway. In S. Bendiksen, M.B. Bringslid \& H.Vike (Eds). Egalitarianism in Scandinavia. Historical and contemporary perspectives (313335). PalgraveMacmillan.

Kenny, C., \& Patel, D. (2017). Norms and reform: Legalizing homosexuality improves attitudes. (Center for Global Development. Working paper 465). Retrieved May 202020 from: https://www.cgdev.org/sites/default/files/norms-and-reformlegalizing-homosexuality-improves-attitudes.pdf

Den norske kirke (2017) Vigselsliturgien [The wedding liturgy]. https:// kirken.no/

Kompetanse Norge [An official directorate in Ministry of Education], Befolkningens bruk av digitale verktøy [The populations's use of digital tools]. Retrieved Jan. 152020 from https:// kompetansenorge.no/statistikk-oganalyze/grunnleggende-digitalferdigheterbefolkningens-bruk-av-digitale-verktoy/

Kreitzer, R. J., Hamilton, A. J., \& Tolbert, C. J. (2014). Does policy adoption change opinions on minority rights? The effects of legalizing same-sex marriage. Political Research Quarterly, 67(4), 795-808. https://doi.org/10.1177/1065912914540483

Kulpa, R. (2013). Western leveraged pedagogy of Central and Eastern Europe: discourses of homophobia, tolerance, and nationhood. Gender, Place \& Culture, 21(4), 431-448. https://doi.org/10.1080/ 0966369X.2013.793656

Lasio, D., \& Serri, F. (2017). The Italian public debate on same-sex civil unions and gay and lesbian parenting. Sexualities, 22(4), 691-709. https://doi.org/10.1177/1363460717713386

Lipka, M (2013, December 12). Eastern and Western Europe divided over gay marriage, homosexuality. Pew Research Center. https:// www.pewresearch.org/fact-tank/2013/12/12/eastern-and-westerneurope-divided-over-gay-marriage-homosexuality/

Makarychev, A., \& Medvedev, S. (2015). Biopolitics and power in Putin's Russia. Problems of Post-Communism, 62(1), 45-54. https://doi.org/10.1080/10758216.2015.1002340

MMI (1998). En telefonundersøkelse om nordmenns holdninger til lesbiske og homofiles rettigheter og levekår [A telephone inquiry about Norwegian attitudes towards lesbians's and homosexual's rights and living conditions]. In: Rapport utarbeidet for NOVA av Erik Dalen. Oslo: MMI (2-4 Mars, 1998).

McCarthy, J. (2015, July 17). U.S. Support for Gay Marriage Stable After High Court Ruling. GALLUP. https://news.gallup.com/poll/ 184217/support-gay-marriage-stable-high-court-ruling.aspx

Ministry of Children and Equality (2004). Retningslinjer for fosterhjem [Guidelines for foster homes]. Retningslinjer av 15 juli til Lov om barneverntjenester av 17 juli 1992 nr. 100. Regjeringen.no. http:// regjeringen.no/nb/dep/bld/tema/barnevern/retningslinjer-forfosterhjem.html?id=415699

Ministry of Health and Care Services (2020). Endringer i bioteknologiloven fra 1 juli [Changes in Law on Biothechnology from 1 July]. Regjeringen.no. https://www.regjeringen.no/no/ aktuelt/endringer-i-bioteknologiloven-fra-1.-juli/id2721705/

Montero, D. (2014). Attitudes toward same-gender adoption and parenting: An analysis of surveys from 16 countries. Advances in Social Work, 15(2), 444-459. https://doi.org/10.18060/16139 
Mühleisen, W., Røthing, A., \& Bang, S. S. (2012). Norwegian sexualities: Assimilation and exclusion in Norwegian immigration policy. Sexualities, 15(2), 139-155. https://doi.org/10.1177/ 1363460712436540

Norwegian Directorate for Children, Youth and Family Affairs [Barneungdoms- og familiedirektoratet - Bufdir]. (2018). Holdninger til lhbti-personer [Attitudes towards lgbti-persons]. Retrieved from https://www.bufdir.no/Statistikk_og_analyse/lhbtiq/Holdninger/

Ohnstad, A. (2008). Skeivt foreldreskap [Queer parenthood]. In B. Puntervold \& B. C. Rappana Olsen (Eds.), Utfordrende foreldreskap- Under ulike livsbetingelser og tradisjoner [Challenging parenthood- Under different conditions and traditions] (73-88). Oslo: Gyldendal Akademisk.

Pallant, J. (2007). SPSS Survival Manual - A step by step guide to data analysis using SPSS for windows ( $3^{\text {rd }}$ ed.). Maidenhead Open University Press.

Perrin, P. B., Smith, E. R., Trujillo, M. A., Rabinovitch, A., \& Coy, A. E. (2018). Differential effects of the supreme court's samesex marriage decision on national support for lesbian, gay, and bisexual civil rights and sexual prejudice. Sexuality Research and Social Policy, 15(3), 342-352. https://doi.org/10.1007/ s13178-017-0302-0

Pistella, J., Tanzilli, A., Ioverno, S., Lingiardi, V., \& Baiocco, R. (2018). Sexism and attitudes toward same-sex parenting in a sample of heterosexuals and sexual minorities: The mediation effect of sexual stigma. Sexuality Research and Social Policy, 15(2), 139-150. https://doi.org/10.1007/s13178-017-0284-y

Roseneil, S., Crowhurst, I., Hellesund, T., Santos, A. C., \& Stoilova, M. (2013). Changing landscapes of heteronormativity: The regulation and normalization of same-sex sexualities in Europe. Social Politics, 20(2), 165-199. https://doi.org/10.1093/sp/jxt006

Røthing, Å., \& Bang Svendsen, S. H. (2010). Homotolerance and heterosexuality as Norwegian values. Journal of LGBT Youth, 7(2), 147-166. https://doi.org/10.1080/19361651003799932

Satka, M., \& Eydal, G. B. (2004). The history of Nordic welfare policies for children. Beyond the competent child: Exploring contemporary childhoods in the Nordic welfare societies, 33-62. Roskilde University Press.
Sloane, J. L., \& Robillard, L. M. (2018). Factors affecting heterosexual attitudes to same-sex marriage in Australia. Sexual Research and Social Policy (15), 290-301. https://doi.org/10.1007/ s13178-017-0276-y

Slootmaeckers, K., Touquet, H., \& Vermeersch, P. (2016). Introduction: EU enlargement and LGBT rights - Beyond symbolism? In K. Slootmaeckers, H.Touquet \& P. Vermeersch (Eds.). The EU Enlargement and Gay Politics. The Impact of Eastern Enlargement on Rights, Activism and Prejudice (1-16). PalgraveMcMillan.

Takács, J., Szalma, I., \& Bartus, T. (2016). Social attitudes toward adoption by same-sex couples in Europe. Archives of Sexual Behavior 45, 1787-1798. https://doi.org/10.1007/ s10508-016-0691-9

The Human Rights Act (1999). Act relating to strengthening the status of human rights in Norwegian law (Lov-1999-05-21-30). https:// lovdata.no/lov/1999-05-21-30

Therborn, G. (2004). Between sex and power: Family in the world, 1900-2000. London: Routledge.

Webb, S. N., \& Chonody, J. (2012). Marriage equality in Australia: The influence of attitudes toward same-sex parenting. Gay \& Lesbian Issues and Psychology Review, 8(3), 165-177.

Webb, S. N., Chonody, J. M., \& Kavanagh, P. S. (2017). Attitudes toward same-sex parenting: An effect of gender. Journal of Homosexuality 64(11), 1583-1595. https://doi.org/10.1080/ 00918369.2016 .1247540

Wilson, K. (2020). Attitudes toward LGBT people and their rights in Europe. In Oxford Encyclopedia of LGBT Politics and Policy. Oxford University Press. https://dora.dmu.ac.uk/handle/2086/ 19811

World Economic Forum (2019). Mind the 100 Year Gap. Weforum. org. Retrieved Oct. 222020 from https://www.weforum.org/ reports/gender-gap-2020-report-100-years-pay-equality

Publisher's Note Springer Nature remains neutral with regard to jurisdictional claims in published maps and institutional affiliations. 